\title{
K SOUČASNÉ TERMINOLOGII RESTAUROVÁNÍ KNIŽNÍ VAZBY*
}

\author{
Jan Novotný (Praha)
}

\begin{abstract}
On the Contemporary Terminology of Book-Binding Conservation
Abstract: The article deals with the current terminology of conservation and historical book binding. The introduction mentions the different paradigms of a scientific examination of a book artefact and lists the fundamental differences between restoration and conservation approaches. The issue of accurate designation is discussed with regard to the technology of book binding, divided in more detail into characteristic structural, protective and decorative elements of the binding and book block, including the typology of the bindings, the sewing structure and the writing material. The etymological development of scientific terminology is treated in connection with a multidisciplinary overlap, theorists and authorities of the field, traditionalism and social usage, the scientific paradigm and normative interpretations, borrowings and literal translations from foreign languages. The study also indicates the semantic vagueness and multiplicity of expressions. In conclusion, the question is raised as to whether it is currently acceptable at all to change the traditional and long-established terminology of historical book binding.
\end{abstract}

Keywords: terminology - book binding - conservation - leather binding - book science

Kniha jako artefakt provází člověka po staletí, jsou v ní zachyceny důležité poznatky z vnímání okolního světa. Informace zaznamenané na psacím materiálu byly pro rychlý a přehledný přistup svázány do kompaktního knižního bloku a celek opatřen ochrannou vazbou. Ve středověkých kodexech a raně novověkých tiscích jsou soustředěny veškeré soudobé znalosti zpracování surovin, výrobní postupy a technologie řady řemesel - zejména pergamenického, koželužského, jirchářského, zámišnického, papírnického, tiskařského, písařského, iluminátorského, truhlářského, tkalcovského, barvířského, kovolijeckého, kovotepeckého, zlatnického, sklářského, řezbářského a ryteckého, a v neposlední řadě knihvazačského. $\mathrm{V}$ průběhu vývoje lidstva se měnila i hmotná podoba knihy. Podle charakteristických konstrukčních, ochranných a zdobných prvků i individuálního řemeslného provedení lze svazek přiřadit $\mathrm{k}$ určitému slohovému období, a mnohdy i ke konkrétní knihařské dílně.

Na knihu můžeme nahlížet z mnoha hledisek. Jednotlivé exempláře lze zkoumat jednak společenskými a humanitními vědami - knihověda, kodikologie, bibliografie, historie, ikonografie, dějiny knižní kultury -, ale i z pohledu př́rodních věd a řemesel - chemie, technologie, klimatologie, mikrobiologie, restaurování, knihařství. Takto byla v minulosti uplatňována odlišná paradigmata vědeckého zkoumání. Zájem knihařu se zaměřoval na maximální zachování užitných funkcí vazby, proto často bývala historická vazba poničena na úkor záchrany textového obsahu. Podobně končila i počáteční snaha chemiků, kteří se snažili „,zakonzervovat" textový obsah domněle stabilními prostředky, těmito ireverzibilními zásahy bývala zpravidla narušena hmotná podstata historických materiálů. Oproti tomu se historici zaměřovali na uměleckou výzdobu vazeb - kompozice, motivy a vzory; ve snaze určit charakteristické zdobné prvky pro konkrétní období s důrazem na výsledný estetický efekt. Později se zájem technologů zaměřoval na navrácení původních vlastností zestárnutých materiálů. ${ }^{1}$ Restaurátoři se spolu s knihovědci počali zabývat studiem knižního artefaktu a jeho upotřebením - provenienčními znaky, řemeslným a knihařským zpracováním, nevyjímaje podrobnější studium konstrukce a struktury knižní vazby, použitých technik, ale i druhotných poškození, historických oprav a estetických úprav, až po specifickou oblast knižní archeologie. ${ }^{2}$

Pro komplexnější bádání je důležitá spolupráce restaurátorů a konzervátorů s chemiky, technology, klimatology, mikrobiology a správci konkrétních sbírek, kterými bývají většinou odborníci z oblasti archivnictví, knihovědy a kodikologie, specialisté na iluminované rukopisy i historickou knižní vazbu. Nejinak je tomu i u veřejně př́stupné Encyklopedieknihy.cz. ${ }^{3}$ Multioborový přesah řešitelského týmu umožňuje zpracovávat rozsáhlejší lexikum

\footnotetext{
* Předložená práce vznikla za finanční podpory Ministerstva kultury v rámci institucionálního financování dlouhodobého koncepčního rozvoje výzkumné organizace Národní muzeum (DKRVO 2019-2023/25.IX.a, 00023272).

${ }^{1}$ Konkrétně metody chemické konzervace kolagenních materiálů (čištění, blokování, tukování), mokrého čištění, bělení a impregnace papíru, př́ípadně metody zpevnění papíru studenou a tepelnou laminací, štěpením.

2 SZIRMAI 1999; VNOUČEK 1992.

${ }^{3}$ Encyklopedieknihy.cz vznikla v rámci výzkumného projektu DG16P02H015 - Knihověda.cz: Portál k dějinám české knižní kultury do roku 1800 (2016-2020, MK0/DG).
} 


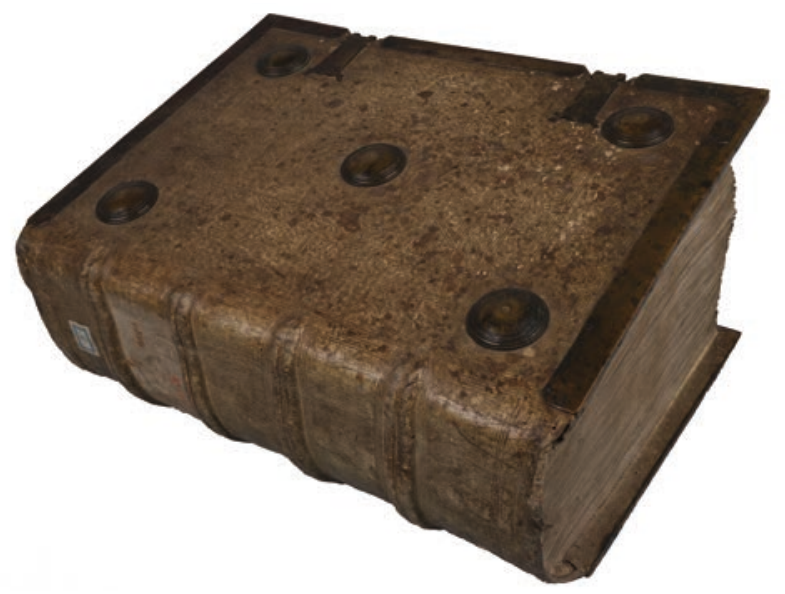

Obr. 1. Gotická celokožená vazba misálu tištěného na pergamenu z počátku 16. století, dřevěné desky opatřeny hranovým kováním a puklami, vpředu dvě háčkové spony, bílá jircha zdobena slepotiskem, kapitálek obšívaný dvěma barevnými nitěmi. Praha, Knihovna Národního muzea, oddělení rukopisů a starých tisků, sign. 42 A 2. Foto: KNM.

výkladových hesel k české knižní kultuře středověku a raného novověku, a v hypertextovém prostředí rozvíjet obsah hesel i po stránce sémantické. Nutno podotknout, že cílem tvůrců encyklopedie není vytvářet závazné terminologické nomenklatury upřednostněním určitých oborových výrazů, nebot' tato činnost vyžaduje vždy širší a dlouhodobější společenský diskurs. Otázky a úvahy nad současnou terminologií pro oblast restaurování historické knižní vazby jsou podrobněji rozvedeny $\mathrm{v}$ tomto prŕspěvku. ${ }^{4}$

V současnosti jsou rozvíjeny všechny dosavadní směry bádání. Restaurátoři ve snaze maximálně zachovat autenticitu, integritu a historickou hodnotu knih upřednostňují konzervátorský prístup, který klade důraz na maximální zachování stávajícího stavu knih. Stále častěji se proto vedle termínu restaurování (angl. conservation i restoration, něm. Restaurierung, fr. restauration) i v češtině prosazuje termín konzervace (angl. conservation, něm. Konservierung, fr. conservation i préservation), jenž vychází především $\mathrm{z}$ anglického názvosloví. Označení „,konservace“ má v tomto směru rovněž dlouhodobou tradici v ochraně tuzemských muzejních a archivních památek, ale i v oblasti knihovědy. Etymologie slova restaurování odkazuje na obnovení stavu předmětu, avšak navrácení předmětu do domněle původního stavu je z hlediska etického neakceptovatelné a obnovení jeho plné materiální funkčnosti prakticky neproveditelné. Naproti tomu termín konzervace poukazuje na potřebu uchování stavu předmětu, i když i ten nejspolehlivější ochranný zásah je časem vystaven procesu stárnutí. ${ }^{5}$

Konzervační zásah vyjadřuje posun od tradičního restaurátorského, jehož cílem je zlepšení užitných funkcí poškozené

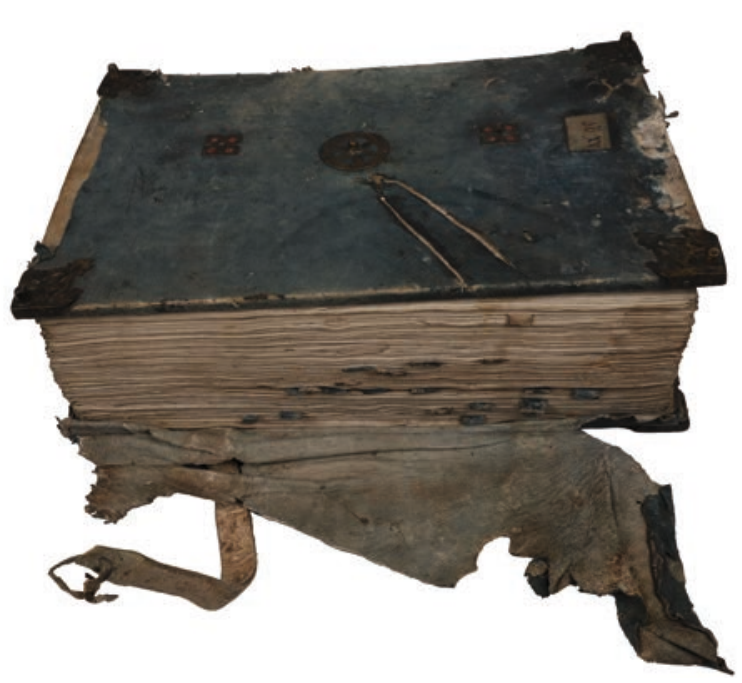

Obr. 2. Gotická obalová vazba pergamenového kodexu z konce 14. století, dřevěné desky potaženy bílou jirchou, přesah obalu z modře barveného zámiše chrání přední ořízku s pergamenovými čtenářskými záložkami, tzv. tenaculum. Praha, Knihovna Národního muzea, oddělení rukopisů a starých tisků, sign. XVI A 10. Foto: KNM.

knihy a zabezpečení hmotného stavu proti potenciálnímu poškozování při manipulaci, směrem k minimalizaci. Součástí minimálního zásahu (angl. minimal intervention) může být dočasné uchycení uvolněných částí vazeb nebo zhotovení ochranného obalu. Výroba krabice typu phase box (do češtiny se nepřekládá) znamená první fázi zabezpečení knihy před dalším poškozováním nebo ztrátou původních částí, než bude rozhodnuto o komplexnějším řešení. ${ }^{6}$ Předpokladem je důsledné dodržování postupů a opatření preventivní péče (angl. preventive care), které směřuje ke zmírňování rizik poškození při manipulaci, uložení, vystavování a badatelských zápůjčkách. Zajištěním vhodných klimatických podmínek prostředí - stabilní teploty a vlhkosti, čistoty vzduchu z hlediska výskytu prachových částic, plynných polutantů a mikrobiální kontaminace - lze výrazně zpomalit nežádoucí degradační procesy a tím i rozpad materiálů. Pro činnosti související s konzervačními zásahy a preventivní péčí se stále častěji prosazuje termín preventivní konzervace (angl. preventive conservation). Na druhou stranu individuální konzervační zásahy, které reprezentují chemické ošetření materiálů, bývají převážně součástí restaurátorských postupů (např. konsolidace barevné vrstvy a inkoustů). Často se však mění chemická a fyzikální struktura historických materiálů, navíc se některé konzervační zásahy mohou aplikovat hromadně na větší množství knih (např. odkyselování papíru, tukování kolagenních materiálů).

Pro přehled o fyzickém stavu sbírek a ke stanovení preventivních opatření, která povedou ke zlepšení podmínek

\footnotetext{
${ }^{4}$ Terminologie k restaurování knižní vazby je v celém článku analyzována na základě dlouhodobého působení autora v profesní sféře restaurátorské a knihovědné, z osobní komunikace, z odborných publikací a oborových vícejazyčných terminologických slovníků citovaných v přehledu použitých informačních zdrojů. Za podněty a připomínky patř́i poděkování především odbornici na preventivní konzervaci a technologii knižní vazby Daně Hřebecké a restaurátorovi historické knižní vazby $M g A$. Karlu Křenkovi.

5 LOSOS 1959, s. 3.

${ }^{6}$ WATERS 1998, s. 113-122. Tento typ krabice tím, že umožňuje pevné sevření svazku, zabraňuje při prudkých klimatických změnách nežádoucímu kroucení a rozevírání desek.
} 
dlouhodobého uložení knihovních fondů, přispívají konzervátorské průzkumy (angl. conservation survey). Posouzení stavu a vyhodnocení rizik spojených s vystavováním originálů se provádí před zápůjčkou. Pro výstavní účely je vyhotovena zpráva o stavu exempláŕe condition report (do češtiny se zpravidla nepřekládá) $\mathrm{s}$ vyobrazením otevřené dvoustrany (tzv. apertury) a uvedením délky vystavení a akceptovatelného osvitu. Kontrolou četnosti vystavování se jednak zamezuje nadměrnému namáhání vazeb, jednak působení nežádoucích účinků světelné energie, které mají kumulativní charakter. O stavu vybavení a zabezpečení výstavních prostor je předkládána zpráva facility report (do češtiny se zpravidla nepřekládá), kterou se vypůjčitel zaručuje dodržovat uvedené klimatické a světelné podmínky a bezpečnostní opatření proti riziku odcizení, poničení nebo poškození exponátů. Pro déle trvající výstavy je z hlediska ochrany jako náhrada originálu upřednostňováno tištěné nebo umělecké faksimile (angl. facsimile, něm. Faksimile, fr. fac-simile) pohledové apertury, které se vkládá do rozevřeného bloku makety vazby. U pri̊zkumu fyzického stavu (angl. condition assessment, něm. Zustand, fr. état) se uplatňují nové poznatky z chemicko-technologické oblasti v souvislosti s vývojem sofistikovaného instrumentálního a diagnostického vybavení. Pro posouzení stavu knižních exemplářu se využívají neinvazivní spektrometrické a spektroskopické metody - jak pro identifikaci materiálového složení, tak i pro stanovení stupně poškození. Tyto nedestruktivní metody se využívají také pro zviditelňování špatně čitelných texti̊, podmaleb a filigránů $\mathrm{v}$ různých vlnových délkách elektromagnetického záření.

Při rozboru materiálové podstaty není termín psací látka, kterým se v pomocných vědách historických označuje jak látka, na kterou se psalo, tak i látka, kterou se psalo, dostačující. Při fyzickém popisu je nutné rozlišit dvě instance - psací materiál a psací látku. V oblasti restaurování se pro psací materiál hojně uplatňuje také termín psací podložka (angl. text support), jenž lépe vystihuje materiálovou podstatu nosiče informace (např. ruční papír, strojní papír, pergamen, papyrus, hedvábí). ${ }^{7}$ Psaci látka reprezentuje záznamový prostředek, kterým se na psací materiál psalo, kreslilo, malovalo, zlatilo nebo tisklo (např. inkoust, pigment, barvivo, plátkové zlato, tiskařská čerň). Ruční papír a pergamen se jako nosné médium vyznačují poměrnou stálostí, degradační procesy však mohou probíhat $\mathrm{v}$ důsledku koroze psací látky - nejčastěji železoduběnkového inkoustu. Někdy se také uvádí v doslovném překladu (tzv. kalku) jako železogalový inkoust (angl. iron gall ink, něm. Eisengallustinte, fr. encre ferro-gallique). ${ }^{8}$

Po vynálezu papírenského stroje vedla zvýšená produkce strojního papíru (angl. machine-made paper, něm. maschinell hergestelltes Papier, fr. papier fait à la machine) ke změně výrobní suroviny - z hadroviny na dostupnější dřevovinu. Po počátečním natronovém způsobu rozvlákňování dřeva se k oddělování ligninu a hemicelulóz od celulózového vlákna počal prosazovat sulfitový postup, buničina se vyráběla vařením dřevných štěpků v roztoku hydrogensirričitanu vápenatého. Navíc se od počátku 19. století začalo pryskyřičné klížidlo s př́́davkem kamence přidávat do papírové suspenze prímo v kádi. Tento kyselý způsob výroby přispívá $\mathrm{k}$ urychlení rozpadu papíru, v případě zaznamenání vyšší kyselosti je proto důležité provést chemickou stabilizaci papíru. Odkyselování (angl. deacidification, něm. Entsäuerung, fr. désacidification) papíru spočívá v neutralizaci volných kyselin a ve vytvoření dostatečné alkalické rezervy, aby přebytek zásaditého činidla redukoval po dobu až několika set let škodlivé účinky volných kyselin a vzdušných polutantů, a tím výrazně napomáhal zpomalit degradační procesy uvnitř papíru. Pro celoplošné zpevnění papíru se podle způsobu provedení použivá celá řada pojmenování - nejčastěji podlepováni, ${ }^{9}$ kašírování, skeletizace, dublování, př́ípadně aplikace na papírovou podložku. Při popisu rezavých skvrn na papíre neurčitého původu (angl. foxing, něm. Stockflecken, fr. Rousseurs), které mohou být způsobené mikrobiálním růstem plísní anebo kovovými nečistotami v papíru za přispění zvýšené vlhkosti a vzdušných kyselin, se upřednostňuje termín foxing ${ }^{10}$ (do češtiny se nepřekládá).

U ručního papíru (angl. hand-made paper, něm. Büttenpapier nebo handgeschöpftes Papier, fr. papier fait-main) se při rovnoměrném nabírání řádně promíchané suspenze papíroviny na čerpací formu, jejíž konstrukci tvoří mosazné síto upevněné na dřevěném rámu a pohyblivý krycí rám, zplstnatělá rostlinná vlákna usazují v tenké vrstvě na povrchu síta. Protože jsou útkové dráty síta po celé ploše podepřené silnějšími osnovními dráty, vzniká pravidelně žebrovaný papír (angl. laid paper, něm. geripptes Papier, fr. papier vergé) s mrrížovanou průsvitkou - tzv. veržé. Na plochu síta je z drátků přiletováno vyvýšené znamení filigrán (angl. watermark, něm. Wasserzeichen, fr. filigrane), které způsobuje po načerpání papíroviny zeslabení vlákenné vrstvy a v průhledu papíru potom vyniká svou průsvitností, proto se někdy tato papírenská značka nazývá ,průsvitkou“. Avšak v první pol. 19. století se objevují filigrány vytvořené vtlačením reliéfního obrazce prímo do papíru egutérem. Protože v papírně nebývalo čerpacích forem mnoho, poskytují filigrány informace o výrobci, místě a době vzniku papíru. Studiem filigránů se zabývá pomocněvědný obor filigranologie. ${ }^{11}$

Současná filigranologie (angl. filigranology, něm. Wasserzeichenkunde i nověji Filigranologie, fr. filigranologie) kromě fotografických technik a moderních metod radiografie a termografie využívá ke zviditelňování filigránů tradiční techniku tužkových obtahů. ${ }^{12}$ Frotáž (angl. rubbing,

\footnotetext{
${ }^{7}$ Nutno však podotknout, že psací podložkou byla dř́ve nazývána kancelářská podložka pro psaní, která byla vyhotovena z papírové lepenky a uzpůsobena pro upevnění povrchového sacího papíru.

${ }^{8}$ Dř́ve zavedený název železitoduběnkový inkoust není zcela přesný, protože inkoust obsahuje kromě duběnek a zelené skalice jak železité ionty, tak i železnaté ionty.

9 Zde nutno odlišit od podlepování knižniho bloku.

${ }^{10}$ Obsáhlá definice foxing $u$ např. ROBERTS - ETHERINGTON 1982.

${ }^{11}$ ZUMAN - VYKYDAL - KORDA 1983; FLODR 1974.

${ }^{12}$ BOLDAN 2011, s. 28-59; BOLDAN - BENEŠOVÁ 2011, s. 117-131.
} 


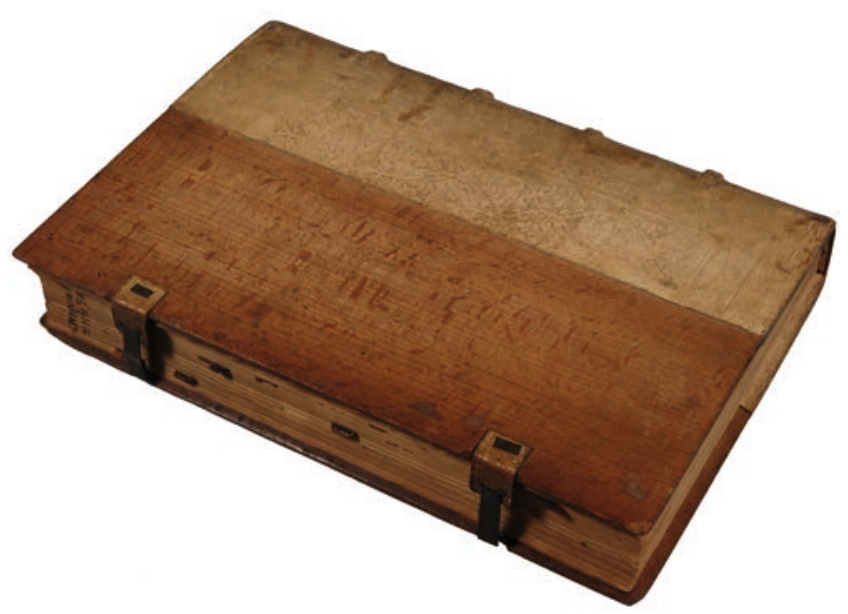

Obr. 3. Pozdně gotická polokožená vazba, bukové desky do třetiny potaženy bílou jirchou, slepotisková výzdoba s rámovou bordurou, vpředu dvě háčkové spony. Praha, Knihovna Národního muzea, oddělení rukopisů a starých tisků, sign. Nostická knihovna G 200. Foto: KNM.

něm. Durchreibung, fr. Frotté) však nachází uplatnění zvláště při zachycení reliéfu slepotiskové výzdoby knižních vazeb, spon a kování. Podstatou slepotisku (ang. blind tooling, něm. Blindprägung, fr. dorure à froid) je vtlačování mírně ohřátého slepotiskového nářadí do vlhké knihařské kůže, která v místě otisku ztmavne. Pro jednoduché a vícenásobné linky se uplatňují mosazné nástroje s dřevěnou rukojetí - filety, kolečka a obloučky. Reliéfní otisk knihařských tlačitek (zastarale „razidel“" nebo „razítek“) s vegetativními, zoomorfními a figurálními motivy se v knihovědných oborech popisuje jako kolek, proto lze tento termín chápat jako synonymní k termínu tlačitko. Některé snahy o rozlišení kolku a tlačítka podle rozměrů nemají v odborné literatuře opodstatnění. ${ }^{13}$ Ornamentální zdobení v pásech usnadňuje práce s knihařskými rolnami (někdy i ,válečky“, zastarale „rouletty“) a negativně rytými kapitálkovými filetami, pro rozměrnější motivy se použivají plotny (v knihařství také „štoček“ i „raznice“). ${ }^{14}$ Po přiřazení shodných otisků slepotiskového nářadí ke konkrétní knihařské dílně je možné přesněji stanovit chronologické a místní určení vazby. ${ }^{15}$

Nejen podle umělecko-řemeslného ztvárnění, ale i podle konstrukce vazby (angl. binding construction i binding structure) můžeme určit, zdali se jedná o vazbu původní, mladší převazbu nebo historickou opravu se zachováním původní struktury šití. Pokud se dochoval pouze samotný knižní blok bez vazby nebo jen jeho torzo, lze nechráněný celek po ošetření uložit bud' do ochranného obalu (např. typu phase box), nebo prristoupit ke zhotovení konzervační vazby. Ochranná konzervační vazba nachází uplatnění i v prŕípadě nefunkční novodobé převazby, avšak eticky přijatelnějším

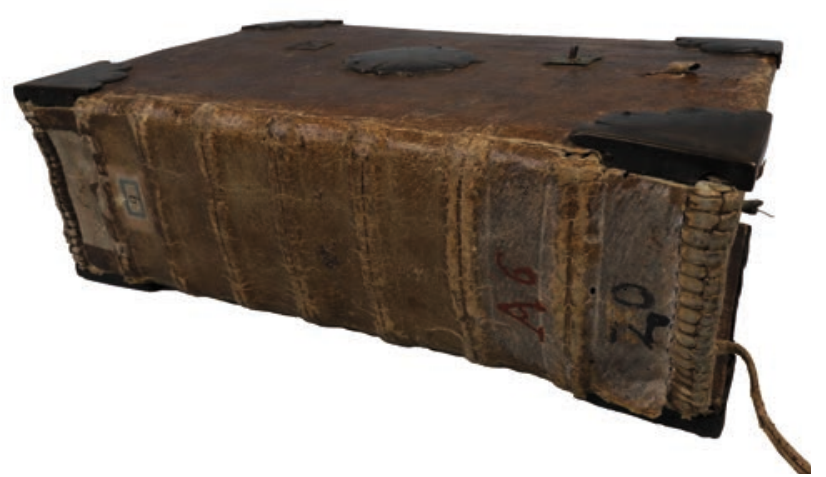

Obr. 4. Masivní celokožená vazba pergamenového kodexu z pol. 14. století, dřevěné desky chráněny nárožním a středovým kováním, vpředu původně dvě dírkové spony (deskové) uchycené trny na přední desce, u hlavy a paty gotické kapitálky oplétané koženým řemínkem, řemínek užit i jako pohyblivá čtenářská záložka. Praha, Knihovna Národního muzea, oddělení rukopisů a starých tisků, sign. XIII B 9. Foto: KNM.

řešením může být rekonstrukce vazby původní. Pro knižní blok se pak vytváŕí domnělá podoba soudobé vazby, podle zachovaných vazeb multiplikátů, vazeb ze stejného období, regionu a obsahového zaměření. Knihařská výzdoba se neprovádí.

Konstrukce vazby se někdy metaforicky uvádí jako „organismus vazby“.${ }^{16} \mathrm{~K}$ tomuto přirovnání zřejmě přispívá pohyblivá funkce mechanismu vazby při otevírání a listování, a rovněž užití organických materiálů. Strukturu šití (angl. sewing structure) tvoří dvoulisty naskládané do složek, které jsou uprostřed ohybu prošity nití. Složky jsou pak bez vazů, anebo s podporou vazů (angl. sewing supports) uchyceny do bloku různými způsoby šití. Takto bývá např́klad šití na pravé vazy u středověkých kodexů pakované (angl. packed sewing, něm. Rundbogenheftung, fr. couture compensée). ${ }^{17} \mathrm{~S}$ nástupem knihařského hoblíku se začaly kapitálkové vazy bud' prrišívat zvlášt' až po ořezání bloku, nebo se odsazené kapitálkové vazy (něm. eingerückter Kapitalband) umíst'ovaly dále od okrajů. ${ }^{18} \mathrm{~V}$ pozdní gotice se obšité kapitálkové jádro z motouzu oplétalo koženým řemínkem i obšívalo barevnými nitěmi v různých variacích.

Knižní blok kodexového typu nebyl opatřen předsádkou, ani volnými předsádkovými listy (někdy také „,předlisty“), nesprávně překládanými z angličtiny jako „lítačka“ (angl. flyleaf, něm. fliegendes Vorsatzblatt, fr. garde volante). K zakončení bloku sloužilo pergamenové křidélko prošité s krajní složkou i šité samostatně, které přesahovalo do třetiny až poloviny bloku a nebylo většinou vylepováno na vnitřní stranu desky - tzv. př́deští. Prošité předsádkové listy s křridélky nacházejí uplatnění v období renesance, křidélka jsou nalepena na prrídeští spolu s prvním předsádkovým listem.

\footnotetext{
${ }^{13}$ Pouze NUSKA 1965, s. 65 popisuje neurčitě kolek jako knihařský nástroj nevelkých rozměrů a razitko jako obdobný nástroj drobnějších rozměrů.

${ }^{14}$ BRADÁČ 1912, s. 205-221; VAKRČKA 1979, s. 198-208.

${ }^{15}$ BOLDAN 2012, s. 201-204.

${ }^{16}$ NUSKA 1965, s. 19-145.

${ }^{17}$ Mezery mezi složkami jsou vyplétány nití, takže šití tvoří na vazu celistvé uspořádání bez mezer. Řada schematických nákresů SZIRMAI 1999.

${ }^{18}$ RHEIN 1942, s. 89-92.
} 


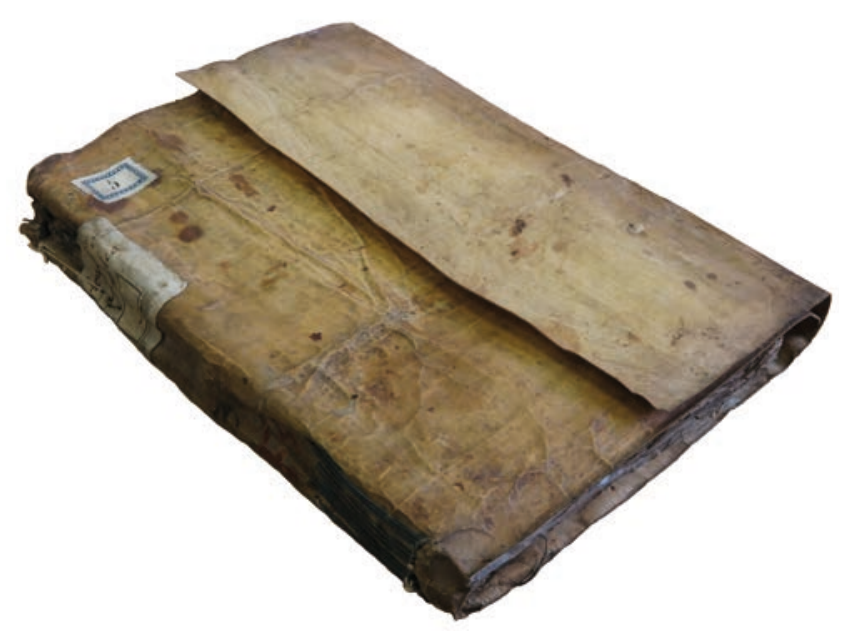

Obr. 5. Gotická měkká pergamenová vazba s klopou u přední ořízky, obálka prošita na hřbetě dlouhým stehem. Praha, Knihovna Národního muzea, oddělení rukopisů a starých tisků, sign. XVI E 5. Foto: KNM.

V období baroka se na předsádky umíst'ují stále častěji ručně zušlechtované papíry - škrobové papíry (angl. paste paper, něm. Kleisterpapier, fr, papier à la colle), mramorované, katunové, velurové, bronzované a ražené brokátové. Mramorovaný papír (angl. marbled paper, fr. papier marbré, něm. Marmorpapier) je odvozen ze vzorů připomínajících mramor, vytvořených na hladině rostlinného slizu. Původní pojmenování „tragantový papír“, podle dříve vyráběného slizu na bázi klovatiny, i „karagenový papír“, podle náhrady tragantu na přelomu 17. a 18. století agarem získaným z červených mořských řas, se již užívá zřídka. Podle způsobu nanášení mramorového vzoru se někdy tento papír obecně uvádí jako „máčený papír“, tento název však zahrnuje širší skupinu dekoračních papírů, včetně olejových. Pravidelný vzor katunového papíru (řidčeji kartounový, angl. block-printed paper, něm. Holzmodelpapier nebo Kattunpapier, fr. papier dominoté) vzniká opakovaným otiskem dřevořezového štočku, u vícebarevného vzoru pak soutiskem několika štočků.

Při restaurování knižní vazby se klade důraz na maximální zachování původní struktury šití. Často se postupuje metodou in situ - tj. bez rozebrání knižního bloku, nebot' řada poškození mechanické povahy se vyskytuje na deskách, vnějším ochranném materiálu a v místech spojení desek s knižním blokem, které se nazývá hřbetní drážka. Termín drážka (angl. hinge nebo joint, něm. Gelenk nebo Scharnier nebo Falz, fr. charnière) zahrnuje všechny součásti vazby, které umožňují otevírání a zavírání desek, proto se někdy podle pohyblivého mechanismu uchycení desek nazývá přeneseně ,„pantem“. Mnohdy uváděný výraz „knižní kloub“19 je ze sémantického hlediska nesprávný, nebot' desky se otevírají $\mathrm{v}$ drážce pouze $\mathrm{v}$ jedné rovině, nikoliv ve více směrech. Při popisu vazby se obvykle rozlišuje mezi vnitřní a vnější drážkou. Vnitřní drážka (angl. inner joint, fr.

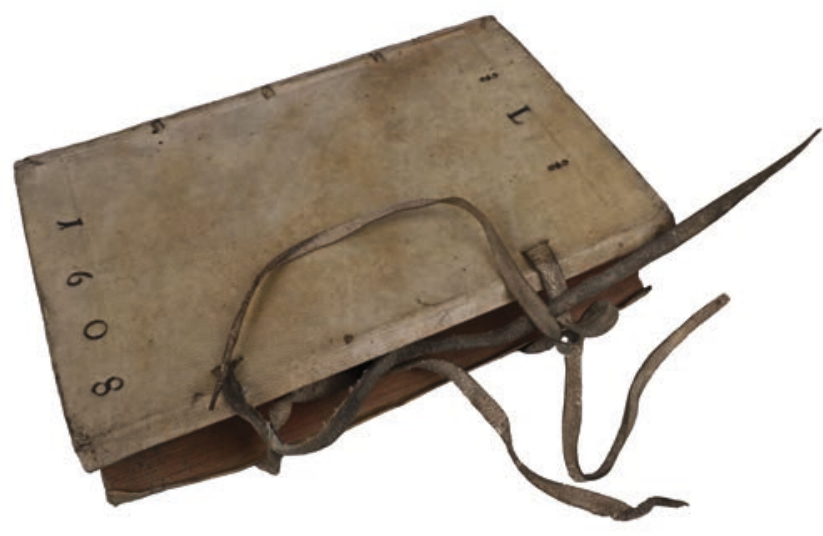

Obr. 6. Renesanční měkká pergamenová vazba s protaženými vazy, holandskými kantami u přední ořízky a se zavazováním na kožené řemínky. Praha, Knihovna Národního muzea, oddělení rukopisů a starých tisků, sign. Knihovna roudnických kapucínů 1642. Foto: KNM.

charnière, něm. Innengelenk) může zahrnovat vazy, kapitálkové vazy, lepené kapitálky, mezivazní přelepy hřbetu, pergamenová křidélka, křidélka předsádkových listů a přesahy výlepů př́ídeští. U měkkých pergamenových vazeb bývají tenké vazy z pergamenu nebo jirchy protaženy dvakrát obálkou, takže jsou v drážce zvnějšku viditelné. Vnějši drážku (angl. outer joint, fr. charnière, něm. Außengelenk) tvoří pokryv nebo potah vazby, povětšinou zakončený u hlavy a paty hlavicemi. Při popisu knižního bloku, vazby i výzdoby se při svislém umístění knihy na regálu horní část knihy označuje jako hlava (angl. head nebo top, něm. Kopf, fr. tête) a spodní část jako pata (angl. tail nebo foot, něm. Schwanz nebo Fuß, fr. queue). ${ }^{20}$ Hlavice (angl. head cap nebo cap, něm. Häubchen, fr. coiffe) je část potahového materiálu, která je v záložkách nasazovaných vazeb nejčastěji nastřižena v drážce, aby ji bylo možné v přechodu desek na hřbet knižního bloku zahnout a zpracovat. Masivní hlavice zpevňují a začišt'ují hřbetní část knihy tím, že u hlavy a paty doléhají těsně ke knižnímu bloku a přesahují přes ořízku, případně kapitálek. U novodobých vazeb je při zakládání uprostřed ponechán drobnější přesah materiálu pro zpracování hlavice do tvaru měsíce. Vyčnívající hlavice s kapitálkem bývají obvykle poškozeny při násilném vyjímání natěsnaného svazku $\mathrm{z}$ regálu.

Při ručním šití dochází u hřbetu k nabytí tloušt'ky knižního bloku, které vzniká opakovaným provlékáním nitě v ohybech složek, u středověkých kodexů i vložením pergamenových zpevňovacích proužků doprostřed složek. Po klížení hřbetu mezi prkénky a případném mírném kulacení vznikne ve hřbetní části pozvolna prohnutý tvar bloku. Tato přirozená nerovnost $\mathrm{v}$ drážce, charakteristická pro ruční zpracování, není z technologického hlediska vyklepávanou hlubokou drážkou, kterou zavedlo až knihařství konce 16. století. Hrany dřevěných desek pak bývají profilovány zevnitř, aby při nasazení lépe přiléhaly na hřbetní část bloku, a z vnější strany, aby ve hřbetní drážce plynule navázaly

\footnotetext{
${ }^{19}$ NUSKA 1986, s. 105-119; BRADÁČ 1912, s. 113; BRADÁČ 1931, s. 27.

${ }^{20}$ Oba termíny se explicitně použivají pro přesné určení prvků vazby (např. kapitálek u hlavy, přelep hřbetu u paty).
} 
na zakulacený (méně často i oblý či zaoblený) tvar knižního bloku. ${ }^{21}$ Hřbet se někdy popisuje jako ,,plochýc“, ale protože se na něm vyskytují různé výstupky, kterými mohou být podle typu vazby jak pravé, tak i falešné vazy, kapitálkové vazy, tvarované hlavice, i hřbetní výztuha měkkých vazeb se zdobnými stehy a knoflíky, pak je výstižnější nekulacený hřbet uvádět jako rovný.

Podle technologie uchycení desek ke knižnímu bloku se rozlišuje vazba nasazovaná, která je v řemeslném pojetí středověké a raně novověké vazby tradičnější, a zavěšovaná. U nasazované vazby (angl. in-board binding) je nejprve spojen blok s deskami. U dřevěných desek tento úkon často obnáší provlečení vazů otvory, jejich zapuštění do vydlabaných žlábků a zakolíčkování; u lepenkových desek nalepení roztřepených motouzů na vnitřní nebo vnější stranu. $\mathrm{V}$ dalších krocích nasazování se nalepují přelepy hřbetu na přídeští desek, teprve potom se kniha potahuje. Nakonec se vnitřní plocha přídeští začistí výlepem, od renesance pak předsádkovými listy s křidélky. Na vylepení se obvykle využívala makulatura - druhotně upotřebený pergamen z rukopisů, papír ze zkušebních nátisků, dobově zastaralá úřední agenda, nástěnné kalendáře tzv. minuce, odpustkové listy apod. $Z$ estetických důvodů bývala makulatura lepena záznamovou stranou dolů, proto je možné určit obsah rukopisů, inkunábulí a paleotypů, který bývá z historického hlediska mnohdy cennější než samotná kniha, až po sejmutí.

U klasické tuhé vazby zavěšované (angl. case binding) se předem potažené desky v závěrečné fázi spojují s blokem knihařským úkonem podlepování. U měkkých pergamenových vazeb (angl. limp vellum binding) se knižní blok zavěšoval do obálky více způsoby. U gotických vazeb byla pergamenová obálka bez záložek ${ }^{22}$ prošita ve hřbetě dlouhým stehem nebo krátkým řetízovým stehem zároveň se šitím knižního bloku. Hřbet byl obvykle vyztužen destičkou ze silnější kůže a opatřen knoflíky pro namotání řemínků, kterými je uchycen pergamen zahnutý přes přední ořízku. Přesah materiálu přecházející na přední nebo i zadní část obálky nejlépe vystihuje termín klopa (zřídka „klopna“, angl. flap nebo fore-edge flap, něm. /Buch/klappe, fr. rabat). Mnohdy uváděný výraz ,(usňová) chlopeň“ je sémanticky přesnější ve spojení „srdeční chlopeň“, nikoliv při popisu knižní vazby. ${ }^{23} \mathrm{U}$ mladších vazeb se obálka zavěšovala nejprve protažením tenkých vazů v ohybech drážky, až poté podlepením předsádek. Pergamen obálky se nezřídka podlepoval ručním papírem, tvarovány byly záložky a hranové přehyby na předních kantách, které tím, že jsou zahnuty kolmo dovnitř, chrání přední ořízku a zpevňují obálku. Obálka $\mathrm{s}$ těmito holandskými kantami se uzavírá převážně zelenými tkanicemi, ale i řemínky z jirchy či pergamenu. Nezřídka užívané spojení „usňové tkanice“ je oxymóronní, nebot' úzké textilní stuhy nemohou být zhotoveny tkaním vyčiněné kůže.

Při popisu knižních vazeb v první řadě více než struktura šití a konstrukce vazby upoutá vnější ochranný materiál a výzdoba. Pro tento „,materiál organického a anorganického pưvodu, který pokrývá desky korpusu“ zavedl teoretik oboru historické knižní vazby prof. PhDr. Bohumil Nuska, CSc., (1932-) v souvislosti s rozborem českých renesančních vazeb termín pokryv. ${ }^{24} \mathrm{~V}$ typologickém přehledu, pojatém jako pomůcka pro datování vazeb, se zaměřil především na uměleckohistorické ztvárnění výzdoby, pro doposud nezpracované typologické znaky nadefinoval nové termíny. Některé v profesní sférée již zavedené termíny se naopak snaží upozadit a nahradit významově podobnými. ${ }^{25}$ Př́kladem může být $\mathrm{v}$ tomto odstavci citovaný neologismus „,knižní korpus“, který má zastoupit zažité spojení knižní svazek, denotující svázaný knižní blok s ochrannou vazbou, v užším slova smyslu pak knihu kodexového typu s potaženými deskami a dalšími ochrannými prvky - kodex.

Termín pokryv (angl. cover, něm. Bezug nebo Überzug, fr. couverture) má mít podle prof. Nusky obecnou platnost a zahrnuje z knihovědného hlediska prakticky cokoliv, čím je povrch knižní vazby chráněn nebo zdoben. Pokryvem takto může být jak potah luxusních vazeb z bohatě vyšívané tkaniny - u románských liturgických kodexů navíc pokrytý zlacenými plechy, drahokamy, emaily či řezanou slonovou kostí -, tak i potah z třísločiněné teletiny na pozdně románské slepotiskové vazbě nebo gotické polokožené řezané vazbě, barvený zámiš na jirchou potažené gotické obalové vazbě, pergamenová obálka měkké vazby, škrobový papír na deskách barokní polokožené vazby, papírová obálka provizorní vazby z 18 . století, mosazné plechy celokovových vazeb z 19. století, ale i druhotné estetické přelepy hřbetu. Jak ze zkráceného výčtu vyplývá, užití termínu pokryv, jakožto jediného akceptovatelného termínu, je zcela nepřesné. Široké a obecné uplatnění pojmu pokryv není v souladu s nomenklaturní tvorbou, nebot' význam každého termínu má spočívat $\mathrm{v}$ co nejpřesnějším vyjádření skutečnosti a v jednoznačné definici oborových entit. Hierarchicky nadřazený pojem pokryv je v knihovědném popisu redundantní, nebot' zcela nepřispívá k identifikaci exempláře. Kniha nemá pokryv pouze v minimálním množství případů - pokud je knižní blok dochován bez vazby, nebo jen s holými deskami bez potahu.

Jako důvod, proč nepoužívat „nevhodného výrazu“ potah, spatřuje prof. Nuska paradoxně i aplikaci jiných „pokryvových surovin, než jsou pokryvné materiály jako useň, pergamen či papír, které mohou navozovat predstavu

\footnotetext{
${ }^{21}$ Hřbet bývá mnohdy popisován jako zakulacený či zkulacený podle technologického postupu nazývaného kulacení hřbetu BRADÁČ 1912, s. 78; HESSEL [19--], s. 13-14; DOLEŽAL 1979, s. 37-38; a zakulacení hřbetu ROŠICKÝ 1894a, s. 9-10. V jiných zdrojích se však tento knihařský úkon uvádí i jako zaobleni hřbetu ŠEDIVÝ 1923, s. 54 (ale v textu již zakulacení hřbetu); VAKRČKA 1969, s. 78; nebo oblení hřbetu KŘÍŽ 1970, s. 73-74. Z profesní praxe je vhodnější přiklonit se $\mathrm{k}$ častěji uplatňovanému termínu prvnímu.

${ }^{22}$ Podle HAMANOVÁ 1959, s. 171 též ,pergamenový obal“.

${ }^{23}$ NUSKA 1965, s. 61-62 použivá termín klopa pouze u měkké obálkové vazby, pro části kủže přesahující boční hrany desek obalových vazeb však upřednostňuje spojení „kožená chlopeň“, jež chrání knižní blok po obalení a pevném sevření desek sponami.

${ }^{24}$ NUSKA 1965, s. $19-145$.

${ }^{25}$ V textu zmíněná netradiční slovní spojení „organismus vazby“, „knižní kloub“, „knižní korpus“, „oblý a plochý hřbet“”, „pokryvový materiál“, „kožený pokryv" atd.
} 


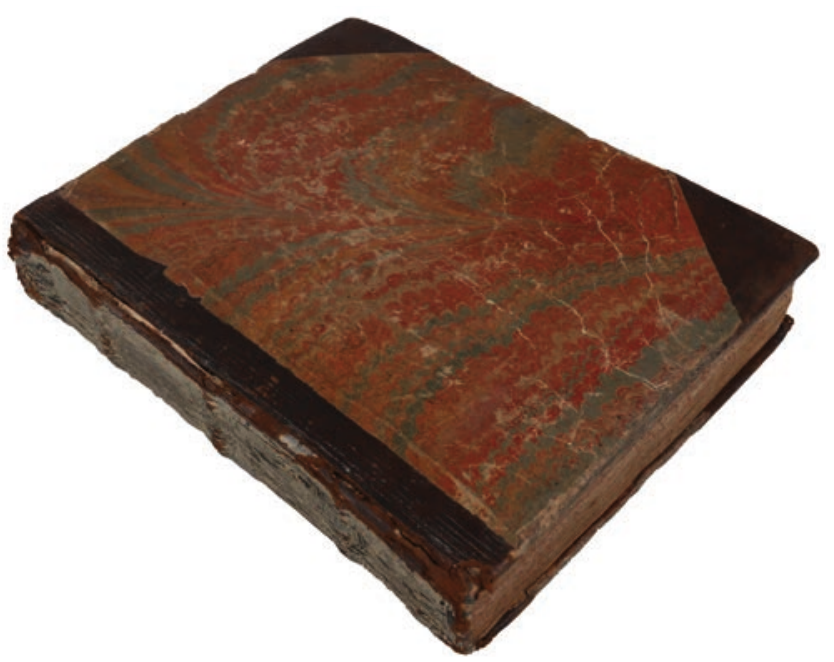

Obr. 7. Barokní polokožená vazba, lepenkové desky potaženy mramorovaným papírem, hřbet přetřen bílou barvou. Praha, Knihovna Národního muzea, oddělení rukopisů a starých tisků, sign. 57 D 119. Foto: KNM.

potahování. Surovinami jako kov nebo kost se desky nepotahuji, ale pokrývaji “. ${ }^{26}$ Termín potah, podobně jako kůži, zařazuje do běžného dílenského žargonu, nebot' nemůže být uznán žádnou knihovědně nebo umělecko-historicky vzdělanou odbornou autoritou. Tímto tvrzením se však teoretik oboru historické knižní vazby dostává do rozporu s metodikou tvorby odborného názvosloví, které mají pro určitou vědní oblast vytvářet vždy odborníci daného oboru. Zde se však naskýtá otázka - kterého oboru zabývajícího se knižní vazbou a kteří odborníci?

Tradiční termín potah (angl. cover, něm. Bezug nebo Überzug, fr. couverture), který má své opodstatnění v knihovědném popisu vazeb, etymologicky vychází z knihařského úkonu zvaného potahování. Potahováni jasně vymezuje technologický postup, u kterého se knihařská kůže po dostatečném vlhčení a proškrobení z rubové strany stává měkkou a vláčnou, takže je možné ji ve vlhkém stavu postupně natahovat směrem od hřbetu na obě desky a tvarovat. V konečné fázi se kưže přetáhne přes okraje desek, založí a po zastřižení zatáhne v rozích. Knihař takto podle technologických příruček, didaktických učebnic a oborových norem pro knižní vazbu desky knihy nepokrývá, ale potahuje. V kontextu tradičního knihařského zpracování je zaveden termín potahový materiál (ang. covering material), kterým mohou být kromě knihařských kůží, pergamenů a textilních materiálů i potahové papiry. ${ }^{27}$ Po technologické stránce je logické použít výraz ,pokrytí“ v př́padě, že na potaženou vazbu bude aplikován mosazný plech, když bude knižní blok opatřen měkkou obálkou nebo potažené desky pokryty ruční výzdobou. Z hlediska tradičního umělecko-řemeslného zpracování

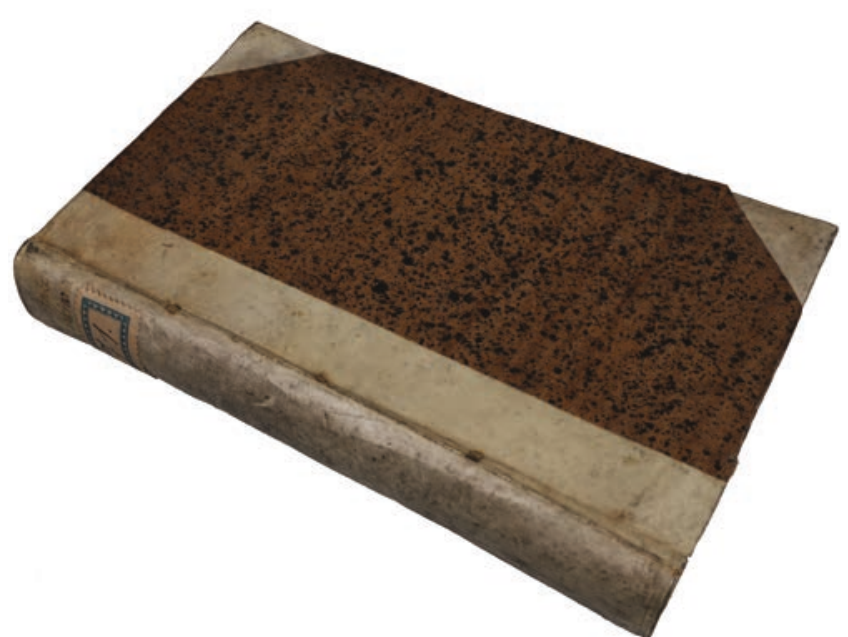

Obr. 8. Barokní polopergamenová vazba, lepenkové desky potaženy škrobovým papírem, pergamenové proužky užité jako vazy protaženy v drážce. Praha, Knihovna Národního muzea, oddělení základní knihovny, sign. 64 F 71. Foto: KNM.

vazeb je tedy termín pokryv prosazovaný prof. Nuskou sémanticky vágní.

Do jaké míry je proto možné akceptovat nomenklaturní zavádění termínů jedinou osobou s vědeckou kompetencí převážně teoretickou, když naproti tomu staletími prověřená knihařská terminologie přesně vystihuje technologické postupy a materiální podstatu historické knižní vazby? Má být sousloví „kožený povlak“ publikované zakladatelem české knihovědy doc. Zdeňkem Václavem Tobolkou (1874-1951) závazné a jediné správné? ${ }^{28}$ Jistá stylistická volnost a bohatší slovní zásoba může být v odborném textu z hlediska poutavosti a čtivosti prospěšná, pokud ovšem široká škála redundantních výrazů nedosáhne až sémantické vágnosti, tak jako je tomu v odborném prŕspěvku k vývoji českého knihařství od prof. Karla Chytila (1857-1934). Př́ popisu vazeb obměňuje výrazy ,potah“, „obal“, ,pokrývka“ a ,povlak“; desky uvádí jako ,potažené“, „,povlečené“, „,obalené“ nebo „,pokryté " kůží. ${ }^{29}$ Přri ohlédnutí ještě dále do minulosti můžeme nalézt ve vícejazyčné učebnici Orbis pictus ${ }^{30}$ vedle vyobrazení knihařské dílny český př̀klad ,,koži povlíká (potahuje) “.

Nutno dodat, že uznávaná odbornice na historickou knižní vazbu PhDr. Pavlína Hamanová (1894-1978) nenazývala povrch vazeb uniformním výrazem ,„pokryv“, ale upřednostňovala podrobnější popis s tradičním názvoslovím jako „kožený potah“ nebo ,potahový materiál““.31 A v knihovědné oblasti není rozhodně jediná, většina odborníků se při popisu knižních vazeb vždy přikláněla $\mathrm{k}$ tradičním termínům. Kromě odborných publikací lze toto tvrzení doložit také stručným výčtem soupisů a katalogů rukopisů a prvotisků. Přední odborníci české kodikologie a knihovědy takto

\footnotetext{
${ }^{26}$ NUSKA 1997, s. $15-16$.

27 VÁVROVÁ - SOUČKOVÁ 2017, s. 91-97.

${ }^{28}$ TOBOLKA 1950. Termín povlak by takto mohl být upřednostněn pro zámišnicky činěnou kůži na raně románské vazbě, která se natahuje za vlhka na desky bez nebo jen s minimálním použitím lepidla, v rozích je sešita a při vysychání pak dochází k jejímu vypnutí a vytvarování.

${ }^{29}$ CHYTIL 1899.

${ }^{30}$ KOMENSKÝ 1833, s. 258.

${ }^{31}$ HAMANOVÁ 1959, na s. 31-32 rovněž ,povlak“.
} 
uplatňovali ve svých bibliografických pracích tradiční odborné názvosloví - (celo)kožená vazba, polokožená vazba, pergamenová vazba, polopergamenová vazba, plátěná vazba, poloplátěná vazba, kǔže, železné hřeby, potah atd. ${ }^{32}$

Druh vnějšího ochranného materiálu a způsob jeho aplikace jsou zásadní pro určení typu vazby. U středověkých kodexů př̀vládá vazba (celo)kožená a (celo)pergamenová. Od konce 15. století se vyskytují nejprve vazby polokožené, u kterých zůstávají dvě třetiny až polovina plochy dřevěné desky holé, od 2. poloviny 16. století se lepenkové desky těchto vazeb již potahují barevně natíraným papírem i druhotně užitým pergamenem. V období baroka se na desky polokožených a polopergamenových vazeb s viditelnými rohy aplikují především potahové papíry - škrobové, mramorované nebo katunové. Navýšení ceny kožedělné suroviny na přelomu 18. a 19. století vedlo v konečném důsledku k stále častější produkci levnějších tuhých (celo)papírových vazeb. Ve snaze napodobit povrchově mořené, stř́kané a mramorované knihařské usně bývají papíry ručně zušlechtovány natíráním, stř́káním, potiskem a později i ražbou. Objevují se rovněž dva typy nakladatelské provizorní vazby s neořezaným blokem - měkká, s papírovou obálkou (angl. case binding, něm. Deckeneinband, fr. emboîtage) a tuhá, s lepenkovými deskami obvykle potaženými papírem. ${ }^{33}$ Až od třetiny 19 . století se průmyslově vyrábí zavěšované vazby (celo)plátěné.

Po vydání Zásad popisu rukopisů Archivem AV ČR $\mathrm{V}$ roce $1983,{ }^{34}$ kde byl jako konzultant pro oddíl 3/11 Vazba přizván prof. Nuska, se objevuje v bibliografických soupisech vedle ustálených popisných spojení - např. ,,desky potažené kưži““, „,desky potažené vepřovicí'“, „desky potažené teletinou“ atd. - také rigidní sousloví „kožený pokryv“, ${ }^{35}$ které má nižší vypovídací hodnotu než doposud užívaná slovní spojení, proto bylo nutné do charakteristik materiálu a barvy pokryvu doplnit údaj „useň a její druh“. Prof. Nuska se nakonec ve svých teoretických př́spěvcích přiklonil k neologismu „usňový pokryv““. ${ }^{36}$ Tuto jazykovou „,nomenklaturu“ částečně převzal do tištěné encyklopedie a do knihovědných prací i historik starší knižní kultury a erudovaný odborník na staré tisky doc. PhDr. Petr Voit, CSc., (1956-). ${ }^{37}$

Také v oblasti umělecké knižní vazby a restaurování se projevila Nuskova snaha o kodifikaci jím vytvářeného názvosloví, aktivně poukazoval na užívání „neodborných výrazů“ na seminárích restaurátorů a historiků, ${ }^{38}$ vyhrocená polemika probíhala i v Knihařském bulletinu vydávaném s podporou Společenstva českých knihařu ${ }^{39}$ Ač s terminologií historické knižní vazby byli nejlépe obeznámeni zkušení restaurátoři, lektorská činnost prof. Nusky v obsáhlé a často citované publikaci zpracované kolektivem autorů $\mathrm{v}$ čele s uznávaným odborníkem na ochranu a preventivní konzervaci archivních a knihovních fondů doc. dr. Ing. Michalem Ďurovičem (1960-) měla zřejmě zásadní vliv i na užití rozdílného názvosloví. V kapitolách věnovaných konzervování a restaurování historické knižní vazby ${ }^{40}$ je patrná určitá terminologická inkonzistence. Vedle zažitých slovních spojení a termínů se paralelně objevují i nově zaváděné - napřr. potah/pokryv, potažení/pokrytí, kožené/usňové, potahový papír / pokryvová useň, kožené řemínky / usňové řemínky, kožené vazby / usňové vazby, ale i „usňový materiál“; někdy se vyskytují v jednom odstavci, nebo dokonce v jedné větě - např. ,desky potaženy papírovým nebo později plátěným pokryvem“. Na pojmovou nepřesnost některých nověji upřednostňovaných termínů bylo v článku již poukázáno - např. ,,pokryv“, ,,pokryv desek“, ,,pokryvový materiál“", „organismus vazby“, „knižní kloub“, „knižní korpus“, „oblý a plochý hřbet", proto bude v poslední části pozornost věnována často nevhodně užívanému a některými restaurátory z Fakulty restaurování Univerzity Pardubice rigidně prosazovanému termínu useň. ${ }^{41}$

Na rozdíl od pergamenu (angl. parchment, fr. parchemin, něm. Pergament), používaného v knižní kultuře jako psací i vazební materiál, se knihařské kůže uplatňují výhradně pro vazební účely jako konstrukční a ochranný materiál. Jemný pergamen nejvyšší kvality, vyrobený z telecí kůže a upravený pro psaní oboustranným broušením, se odborně nazývá vellum $^{42}$ (angl. vellum, fr. vélin, něm. Pergament). Pro knihařské práce musí vyčiněná kůže získat kromě měkkosti, vláčnosti a ohebnosti i další užitné vlastnosti - zvláště trvanlivost, pevnost a odolnost. Tomuto požadavku vyhovují kůže zpracované tradičními koželužskými postupy, staletími prověřené na historických vazbách. Ve výčtu odborných knihařských publikací, ${ }^{43}$ knihovědných monografii ${ }^{44}$ a vědeckých statí o konzervaci ${ }^{45}$ se termín „useň“ neobjevuje. V knihovědné publikaci ${ }^{46}$ od PhDr. Mirjam Bohatcové, CSc., (1919-2007) se useň vyskytuje, ale při bližším rozboru zjistíme, že pouze

\footnotetext{
${ }^{32}$ DOKOUPIL 1957; VAŠICA - VAJS 1957; PRAŽÁK 1969; RYBA 1979; RYBA 1980; PRAŽÁK 1980; SVOBODOVÁ 1996; BRODSKÝ 2000; DOKOUPIL - BAR 2011; DRAGOUN 2011; srov. OTTU゚V SLOVNÍK 1899, s. 439-441, heslo Knihařství.

${ }^{33}$ Nenáročné vazby jsou určené k prozatímní ochraně neořezaných tiskařských archů, než podstoupí nákladnější knihařské zpracování.

${ }^{34}$ PRAŽÁK - HOFFMANN 1983.

${ }^{35}$ HOFFMANN - PAŘEZ 1999; PETR 2007; ZACHOVÁ - PETR 2010.

${ }^{36}$ Srov. NUSKA 1965, s. 19-145 a NUSKA 1986, s. 119.

${ }^{37}$ VOIT 2006; VOIT 2015

${ }^{38}$ NUSKA 2003, s. 52-65.

${ }^{39}$ Takto např. reakce NUSKA, Bohumil. Ještě jednou: pokrýváme nebo potahujeme? KNIHAŘSKÝ BULLETIN 3, 1999, s. 15-16 na příspěvek VANĚK, Oldřich. Skutečně pokryv? KNIHAŘSKÝ BULLETIN 2, 1999, s. 25. Další reakce s terminologickými komentáři NUSKA, Bohumil. KNIHAŘSKÝ BULLETIN 1, 2000, s. 21; KRÁL, Jindřich. Tamtéž, s. 22-26 a SOBOTA, Jan. Tamtéž, s. 26-29 na recenzi VANĚK, Oldřich. Jaké je Moderní knihařství? KNIHAŘSKÝ BULLETIN 3, 1999, s. 28-30.

${ }^{40}$ DUUROVIČ 2002, kap. 8, s. 349-436.

${ }^{41}$ SLOVIK - SOJKOVÁ - KOPÁČIK 2015

${ }^{42}$ Existuje také český odborný název „,velín“ (někdy i „velin“), od něhož je odvozen hladký velinový papír.

${ }^{43}$ ROŠICKÝ 1894a; CHYTIL 1899; ŠETLÍK 1910, s. 26-31; HESSEL [19--]; BRADÁČ 1931; KŘ́ÍŽ 1970; VAKRČKA 1979; DOLEŽAL 1987.

${ }^{44}$ TOBOLKA 1950; HAMANOVÁ 1959.

${ }^{45}$ VOJTÍŠEK 1914; STOCKÝ 1927; VOJTÍŠEK 1932; HRÁSKÝ 1948; LOSOS 1959; GALAMBOŠ 1983, s. 108-137.

${ }^{46}$ BOHATCOVÁ 1990.
} 


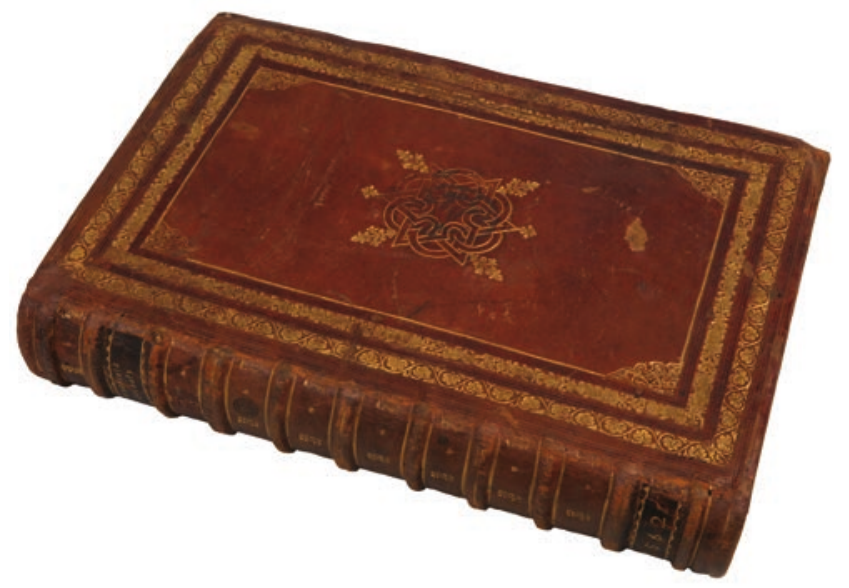

Obr. 9. Renesanční celokožená vazba s lepenkovými deskami, červeně mořená useň zdobena zlacením $v$ dominantové kompozici. Praha, Knihovna Národního muzea, oddělení rukopisů a starých tisků, sign. 16 A 1. Foto: KNM.

v kapitolách psaných prof. PhDr. Bohumilem Nuskou, CSc. Ten se v rozsáhlé typologii renesančních vazeb snažil rozlišit pojmenování pro základní surovinu kůže (angl. skin a pro velká dospělá zvírata hide - např. cowhide, horsehide, něm. Haut, fr. peau) a pro výsledný produkt useň (angl. leather, něm. Leder, fr. cuir) - „,prevládajicím materiálem pokryvu renesančnich vazeb je kůže v podobě mořené nebo nemořené usně, pergamenu nebo kůži různého zpracování a částečně pergamenového vzhledu “. ${ }^{47}$ Názvosloví pro knižní vazbu a formulaci etických zásad restaurování konzultoval s Josefem Vyskočilem (1899-1980), ústředním konzervátorem nad knižními fondy státních vědeckých knihoven. ${ }^{48}$ Restaurátor J. Vyskočil spolupracoval od 50. let s Výzkumným ústavem kožedělným v Otrokovicích na vývoji kvalitních knihařských kůží a pergamenů, které byly experimentálně vyráběny podle historických receptur pro úzkou skupinu zájemců. Takto se v Ročence Universitní knihovny v Praze z roku 1956 poprvé objevuje sousloví „vazební usně“، ${ }^{49}$ Výraz ,useň“ se př́íhodně přebírá z obuvnického a oděvního průmyslu, aby byl zřejmý účel užití pro knižní vazbu, je doplněn přívlastkem „vazebni““. Na spolupráci navázalo Restaurátorské a konservačni oddělení Státni knihovny ČSR koncem 70. let vývojem konzervačních metod pro historické ,trrísločiněné vazební usně“،, „,bílé vazební usně“" a ,pergameny“.

Používání slova useň v oblasti historické knižní vazby, jak se tomu v současnosti děje, však neodpovídá jeho významu. A to obzvláště ve spojení „,bílé vazební usně“. Toto tvrzení lze doložit citacemi ze starších informačních pramenů. Při podrobnějším zkoumání etymologie slova v Ottově slovníku naučném je při nalezení hesla „Useň“ uveden odkaz

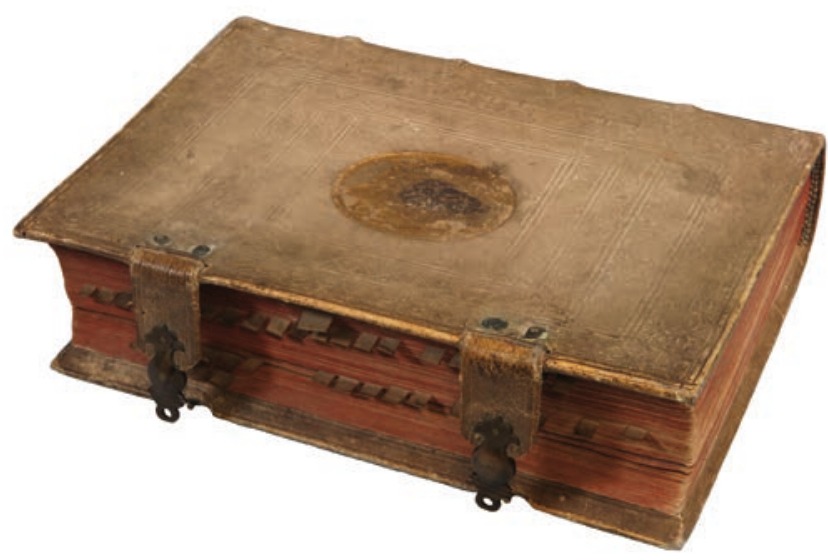

Obr. 10. Pozdně barokní celokožená vazba, bílá jircha zdobena slepotiskem a zlaceným supralibros, svazek sevřen dvěma dírkovými (hranovými) sponami uchycenými na hraně přední dřevěné desky na trny zakončené hlavicí, na červeně barvené ořízce nalepeny pergamenové čtenářské záložky, dvoubarevně obšívaný kapitálek. Praha, Knihovna Národního muzea, oddělení rukopisů a starých tisků, sign. 18 B 6. Foto: KNM.

„viz Koželužství“. ${ }^{50}$ Po důležité větě - ,,Surová kůže vyděláváním koželužským precházi v látku trvanlivou, měkkou a hebkou, tzv. useň “ - následuje popis př́pravy holiny pro její další zpracování. Pro pochopení významu slova useň jsou naprosto klíčové věty - , Vyděláváni koželužské, jež po těchto pracích připravných následuje, liši se podstatně od vydělávání jirchářského a zámišnického. Jirchář uživá soli hlavně hliněných, zámišník vydělává kůži mechanicky tukem, koželuh však dodává jí potřebné vlastnosti látkami z řiše rostlinné, jako jsou predevším tříslo a duběnky ... ". ${ }^{51}$ Není proto velkým překvapením, když $\mathrm{v}$ tomto slovníku nalezneme kromě hesla „Useň (viz Koželužství)“ ještě samostatné heslo „Jircha“"52 - „Kưže na mékko vydělaná kamencem“ s odkazem „viz Jirchářství“. Heslo podrobně popisuje způsob vydělávání jirchy - ,Jirchářství jest druh minerálního vydělávání kůže, při kterém se kůže na líci vlasu a pokožky, na rubu tukové vrstvy a blan dle stejných zásad jako v koželužství zbavuje a pred hnitím chrání tím, že se napoji roztokem kamence ... “. Ve slovníku je uvedeno rovněž samostatné heslo „Zámišs ${ }^{653}$ „,̌. leš, ... príprava její jest podobná jako u jirchy, liši se od ní tím, že po ... natírá se po obou stranách olejem neb rybím tukem. Dokončující úprava jest táž jak u jirchy. “. Konzistentně je useň vymezena i v často citované učební príručce Františka Černého - , Vyděláním koželužským prechází v látku měkkou, trvanlivou, $t z v$. usen̆ " ${ }^{54}$ proto se u dalších způsobů činění slovo useň již nevyskytuje. V obsáhlém přehledu koželužství od Václava L. Rošického je sémantický výklad slova podobný - ,,kůže po koželužsku vydělaná, useń zvaná, ... není tak

\footnotetext{
${ }^{47}$ NUSKA 1965, s. 19-145.

${ }^{48}$ Se sídlem v tehdejší Národní a univerzitní knihovně.

${ }^{49}$ ROČENKA 1958.

${ }^{50}$ OTTŮV SLOVNÍK 1907, s. 239, heslo Useň.

${ }^{51}$ OTTŮV SLOVNÍK 1899, s. 1057-1058, heslo Koželužství.

52 OTTŮV SLOVNÍK 1898, s. 548, heslo Jircha.

${ }^{53}$ OTTŮV SLOVNÍK 1908, s. 421, heslo Zámiš.

${ }^{54}$ ČERNÝ 1923, s 14.
} 
poddajná jako předešlé dva druhy “. ${ }^{55} \mathrm{~V}$ jiném kontextu, nežli je pojmenování výsledného produktu třísločinění, se slovo useň nevyskytuje ani $\mathrm{v}$ obsáhlých dějinách řemesel a obchodu od historika Zikmunda Wintra - ,usenníci a koželuzi vydělávali kůže na rudo (tj. tř́sločiněním) “. Úryvek z tohoto díla přináší podstatnou informaci $\mathrm{k}$ etymologii slova useň: „,Odvětvím koželuhů jsou usenníci, kteři krájeli usně a prodávali na kusy pasírùm a jiným řemeslům kožemi pracujícím. Prodával-li koželuh kůže celé, byli usenníci spíš tedy koželuhů odvětvím po stránce obchodní. "56 Podle tohoto určení pak je doloženo, že byly ,,prodávány vydělané kưže celé, usně neboli kůže krájené, vazy, okrajky".57

Existují tedy vedle sebe tři rozdílné způsoby vydělávání kůže, jejichž produktem je useň, jircha a zámiš. Z tohoto důvodu je pojmenování „useň světlá bílá“ nebo „bílá vazební useň“ zavádějícíi ${ }^{58}$ Postup zpracování surové kůže je až do fáze holiny stejný jako při výrobě pergamenu. Holina se však dále vydělává činěním, kterému předchází obvykle enzymatické moření psím, holubím nebo slepičím trusem. Toto moření kưží, jehož účel spočívá v odstranění přebytků vápna a otevření vláknité struktury pro lepší prrístup činidla, je podstatné terminologicky odlišit od moření usní roztoky železitých solí nebo silných alkálií, které reakcemi s taninem mění barevnost usní. Jirchy a zámiše neprochází procesem tř́sločinění, proto je nelze mořit, ale barvit. Je nutné si uvědomit, že požadavky na kvalitu kůže pro (historickou) knižní vazbu se od oděvní a obuvnické usně zásadně liší. Nutno dodat, že v současnosti nabízené ,vazební usně“, jejichž výroba je v rámci spotřebního průmyslu urychlována novodobými chemickými postupy (např. aldehydickým činěním, činěním minerálními solemi na bázi chromu), nejsou oním materiálem, který byl v minulosti aplikován na knižní vazbu. Lze pak tradičními koželužskými postupy zpracované knihařské kůže zaměňovat za „vazební usně“"?

$\mathrm{V}$ angličtině se podobně jako v češtině pro surovinu a výsledný produkt užívá dvojí označení - „skin“ a „leather“. Vzhledem k tomu, že zavádějící výraz „leather“ (překládaný obecně jako useň) konotuje jak s rostlinnými tříslivy činěnou kůží (usni), hlinitými solemi činěnou kůží (jirchou $^{59}$ ), tak i s tukem činěnou kůží (zámišem ${ }^{60}$ ), doporučuje přední odborník na knižní vazbu Bernard $C$. Middleton
(1924-2019), aby pro rozlišení postupu vydělávání bylo upřednostňováno dvouslovní pojmenování - „tanned skin“ (trrísločiněná kůže), ,,allum-tawed skin“ (hlinitočiněná kůže) a „oil-tanned skin“" (tukočiněná kůže). ${ }^{61}$

V současnosti dochází také v češtině k nežádoucímu posunu původního významu slova useň a $\mathrm{k}$ zobecnění pojmu na všechny druhy vyčiněných kůží. Důvody lze spatřovat $\mathrm{v}$ ústupu tradičního knihařského řemesla a v postupném odklonu oboru restaurování od knihařské praxe. Při ochraně knih je dáván důraz na jedné straně na technologicky méně složité a ve větší míře aplikovatelné konzervační techniky, ${ }^{62}$ na druhé straně jsou kladeny vyšší požadavky na znalosti z knihovědných a chemicko-technologických oborů. S postupnou změnou paradigmatu oboru restaurování se také kladou větší nároky na multidisciplinární spolupráci, přehnaná tendence působit vědecky vede $\mathrm{k}$ neopodstatněné snaze měnit předchozími generacemi zažité profesní názvosloví a vytvářet novotvary. Dochází tak ke střetu dvou směrů společenského diskursu - profesního a akademického. Tento trend je patrný zejména v litomyšlském Ateliéru restaurování papíru, knižní vazby a dokumentů Fakulty restaurování Univerzity Pardubice. Př́́kladem může být prríspěvek z roku 2018 publikovaný v tomto sborníku, který se zabývá tematicky zajímavým průzkumem celokovových vazeb z 19. století. ${ }^{63}$ Mnohočetné užití pojmově neurčitých výrazů ,pokryv“, „pokrytí“ a ,pokrytá“ ve spojeních ,plocha desky pokrytá usní“ a „plocha desky pokrytá mosazným plechem“ vede ke zmatení čtenáře, který jen těžko odlišuje, co je základní potah desek a co druhotné pokrytí plechem. Přesto, že existují společenskou uzancí ustálené české termíny celokožená vazba a polokožená vazba, jsou v článku zastoupeny litomyšlskou školou rigidně prosazované novotvary „celousňová vazba“ a „polousňová vazba““.64 Naskýtá se proto otázka, zdali je eticky akceptovatelné měnit podle označení „useň“, jehož obecné uplatnění je navíc na základě uvedených skutečností diskutabilní, ${ }^{65}$ již zavedenou nomenklaturu a typologii historických knižních vazeb, a tím posouvat i pojmovou podstatu časem prověřených kožených a polokožených vazeb?

Objevují se ambice vytvářet další nová spojení, ve kterých je slovo kůže automaticky nahrazováno slovem

\footnotetext{
${ }^{55}$ ROŠICKÝ 1894b, s. 78; stejný výklad slova useň BALDA - POKORNÝ 1862, s. 236-244; a další zdroje.

${ }^{56}$ WINTER 1906, s. 443.

${ }^{57}$ WINTER 1906, s. 859; doplněno poznámkou: , Koželuzi dnes zovou koži vlastně jen surovinu, jak se z dobytka stáhne, zpracovanou kůži pak zovou usní. Že v staré době useñ znači kůži krájenou, to soudíme napr̆. z rádu krumlovských koželuhů, kde se ukládá cechmistrům ohledávati kůže dělané a usně krojené. Nebo z řádu novoměstského, kdež stoji usně hostinské (přespolní) nemaji prodávány býti než na jarmarce, ale kĩže celé hostinské mohou v trhové dni prodávány býti. “

${ }^{58}$ NUSKA 1965, s. 64; К̌EHÁK - ORLITA 1986.

${ }^{59}$ Bílá jircha činěná kamencem $\mathrm{KAl}\left(\mathrm{SO}_{4}\right)^{2} \mathrm{~s}$ př́idavkem kuchyňské soli $(\mathrm{NaCl})$ po delším namočení ve vodě opět přechází v holinu.

${ }^{60}$ Zámišnicky činěná kủže tukem a rostlinnými oleji se lidově uvádí také jako ,jelenice“. Z obuvnického a rukavičkářského průmyslu je převzat opět nevhodný výraz „semiš“

${ }^{61}$ LANGUAGE OF BINDING. Heslo „Tanned skin“ převzato z MIDDLETON 1994, s. 117.

${ }^{62}$ Např́íklad spravování poškozených vazeb přibarveným japonským papírem.

${ }^{63}$ SLOVIK-VÁVROVÁ - SLOVIK 2018, s. 96-104.

${ }^{64}$ Tradiční termíny celokožená vazba a polokožená vazba jsou zastoupeny i v internetové Encyklopedieknihy.cz. Výkladová hesla pro tištěnou knihu poskytl z tištěné encyklopedie VOIT 2006 historik starší knižní kultury a literární historik doc. PhDr. Petr Voit, CSc., (1956-) hesla pro knižní vazbu zpracoval odborník na počátky knihtisku PhDr. Kamil Boldan (1966-), restaurátor PhDr. Jan Novotný (1973-) a kodikolog Mgr. Michal Dragoun (1974-). Ten v praktickém návodu pro popis středověkých kodexů DRAGOUN 2018, s. 102-116 nadále preferuje tradiční termín kožená vazba, kontextově použíá potah i pokryv.

${ }^{65}$ Podle významu termínu „usňová vazba“ tak, jak je doložen v tomto článku, by musely ekvivalentně vzniknout také nové termíny ,jirchová vazba“ a „zámišová vazba“, všechny hierarchicky podřazené termínu kožená vazba.
} 
useň - ,usňový řemínek“, ,usňové vazy“, ,usňové proužky“, „usňové ucho“ nebo „tenčení usně“, ale i další spojení např. „ocelové hřeby“, „ocelové kování“, které však nebudou dále rozebírány. $\mathrm{K}$ věcným argumentům uvedeným $\mathrm{v}$ tomto příspěvku, které snad přesvědčivě směřují proti tomuto trendu, lze závěrem přidat i paralelní srovnání s doslovnými cizojazyčnými překlady (tzv. kalky). Doslovným překladem termínů „watermark“ z angličtiny nebo „Wasserzeichen“ z němčiny získáme pro oblast historické knižní vazby nepřijatelného termínu ,vodoznak“, jenž je v českém prostředí upřednostňován pro vodní značku parního kotle, nikoliv pro filigrán. U některých výrazů je obtížné najít český ekvivalent, proto se raději nepřekládají - např. phase box, condition report, facility report, foxing. Pro volné predsádkové listy (někdy také ,předlisty“, angl. flyleaves, zastarale flying leaves) již čeština tradiční termín má, proto jakýkoliv pokus o doslovný překlad typu „lítačky“ není namístě. Podobně je tomu i se souslovími ,leather binding“ a ,half-leather binding“, kdy vznikají již rozebírané novotvary „celousňová vazba“" a „polousňová vazba“. ${ }^{66}$

\section{Seznam použité literatury:}

BALDA - POKORNÝ 1862: BALDA, Josef-POKORNÝ, Martin. Základové technologie. V Praze: I.L. Kober, 1862. Průmyslová škola; 10, s. 236-244.

BOHATCOVÁ 1990: BOHATCOVÁ, Mirjam et al. Česká kniha v proménách staletí. Praha: Panorama, 1990.

BOLDAN 2011: BOLDAN, Kamil. Filigranologie a datace nejstarších plzeňských tisků. In: Minulostí Západočeského kraje XLVI. [Ústí nad Labem]: Albis International, 2011, s. $28-59$.

BOLDAN - BENEŠOVÁ 2011: BOLDAN, Kamil BENEŠOVÁ, Marie. Metody vizualizace filigránů a využití filigranologie pro datování nejstarších českých tisků na příkladu tzv. Nového zákona se signetem. In: NOVOTNÝ, Jan (ed.). Výzkum a vývoj nových postupů v ochraně a konzervaci pisemných památek (2005-2011): sborník príspěvki̊ závěrečného semináře $k$ výzkumnému záměru MK00002322103. Praha: NK ČR, 2011, s. 117-131.

BOLDAN 2012: BOLDAN, Kamil. Einbanddatenbank a její využití při studiu knižních vazeb. In: Bibliotheca antiqua 2012: sbornik z 21. konference, 7.-8. listopadu 2012, Olomouc. Olomouc: Vědecká knihovna v Olomouci, 2012, s. 201-204.

BRADÁČ 1912: BRADÁČ, Ludvík. Knihvazačství. V Praze: Jan Laichter, 1912. Umění a řemesla.

BRADÁČ 1931: BRADÁČ, Ludvík. Knižní vazba v proměnách věkư. Praha: [Ludvík Bradáč], 1931.

BRODSKÝ 2000: BRODSKÝ, Pavel. Katalog iluminovaných rukopisu Knihovny Národního muzea v Praze. Praha: KLP, 2000. Studie o rukopisech. Monographia, vol. 5.

ČERNÝ 1923: ČERNÝ, František. Vydělávání, moření, mramorování a barvení kůže. V Praze: Ústř̌ední státní ústav grafický, 1923.
DOKOUPIL 1957: DOKOUPIL, Vladislav (ed.). Soupis rukopisů knihovny augustiniánů na St. Brně. Praha: Státní pedagogické nakladatelství, 1957. Publikace vědecké literatury. Soupisy rukopisných fondů Universitní knihovny v Brně; sv. 1.

DOKOUPIL - BAR 2011: DOKOUPIL, Vladislav - BAR, Přemysl. Soupis rukopisů dačických františkánů. Brno: Moravská zemská knihovna, 2011.

DOLEŽAL 1987: DOLEŽAL, Jaroslav. Vazby knih. Praha: SNTL, 1987. Polytechnická knižnice. III. řada: udělejte si sami; sv. 13.

DRAGOUN 2011: DRAGOUN, Michal. Soupis středověkých rukopisů Knihovny Národního muzea: doplňky ke katalogům F. M. Bartoše, J. Vašici a J. Vajse. Praha: Národní muzeum, Scriptorium, 2011.

DRAGOUN 2018: DRAGOUN, Michal. Středověké rukopisy $v$ českých zemích: handbušek kodikologa. Praha: Scriptorium, 2018.

ĎUROVIČ 2002: ĎUROVIČ, Michal et al. Restaurování a konzervování archiválií a knih. Praha: Paseka, 2002.

FLODR 1974: FLODR, Miroslav. Filigranologie: úvod do studia filigránů. Brno: UJEP, 1974.

GALAMBOŠ 1983: GALAMBOŠ, Ivan et al. Konzervace a restaurování historické knižní vazby. Sborník archivních praci 33, 1983, č. 1, s. 108-137.

HAMANOVÁ 1959: HAMANOVÁ, Pavlína. Z dějin knižní vazby: od nejstarších dob do konce XIX. stol. Praha: Orbis, 1959.

HESSEL [19--]: HESSEL, Antonín. Knižní vazba. V Praze: nákladem Jednoty dělnictva knihařského a prríbuzných odvětví, [19--].

HOFFMANN - PAŘEZ 1999: HOFFMANN, František PAŘEZ, Jan (ed.). Soupis rukopisů knihovny kláštera premonstrátů Teplá. Praha: Archiv AV ČR, 1999. 2 sv. Studie o rukopisech. Monographia; sv. 3.

HRÁSKÝ 1948: HRÁSKÝ, Josef. Konservace archiválií. In: Archivní príručka: sborník přednášek o archivni praxi. V Praze: Čs. archivní společnost, 1948.

CHYTIL 1899: CHYTIL, Karel. Dějiny českého knihařství. V Praze: Společenstvo knihařů, 1899.

KNIHǍ̌SKÝ BULLETIN 1995-2000: Knihařský bulletin: čtvrtletní zpravodaj pro uměleckou knižní vazbu a souvisejicí obory. Černošice: ARCUS, 1995-2000.

KOMENSKÝ 1833: CHMELA, Josef (ed.). KOMENSKÝ, Jan Amos. Joan Amos Comenii Orbis pictus = Die Welt in Bildern $=$ Swět $w$ obrazých $=$ Świat $w$ obrazach $=$ Le monde en tableaux. W Hradcy Králowé: Pjsmem Jana Host. Pospjšila, 1833.

Ǩ̌ÍŽ 1970: KŘÍŽ, Jaroslav. Průmyslové knihařství. Praha: Nakladatelství technické literatury, 1970. Knižnice Typografia. MIDDLETON 1994: MIDDLETON, Bernard. A history of English Craft Bookbinding Techniques. London: The British Library, 1994.

LOSOS 1959: LOSOS, Ludvík. Nové metody konservace musejních sbírek. V Praze: Národní muzeum v Praze, 1959.

\footnotetext{
${ }^{66}$ Pokud bude etymologický vývoj bez širšího diskursu směřovat tímto směrem, začnou se objevovat s nadsázkou i taková spojení jako „usněnkový pokryv“ pro koženkový potah? Vzniknou také oxymóronní spojení „,pravá př́rodní useň“ pro pravou přírodní kůži, anebo budou kožené holinky označeny přívlastkem „usňové“, užívaným pro výsledný produkt tř́sločinění holiny? Zůstane hmyzí škůdce kožojedem obecným?
} 
NUSKA 1965: NUSKA, Bohumil. Typologie českých renesančních vazeb. In: Historická knižni vazba: sborník př́spěvků $k$ dějinám vazby a $k$ metodice ochrany historických knižních vazeb 1964-1965. Liberec: Severočeské muzeum, 1965, s. 19-145. Odborné a metodické př́ručky Severočeského musea, sv. 3-4.

NUSKA 1986: NUSKA, Bohumil. $K$ morfologii historického knižního korpusu kodexového typu. In: Sborník Severočeského musea. Historia 8. Liberec: Severočeské museum, 1986, s. 105-119.

NUSKA 1997: NUSKA, Bohumil. Potah nebo pokryv? In: Knihařský bulletin 4, 1997, s. 15-16.

NUSKA 2003: NUSKA, Bohumil. Otázky restaurování vazeb úředních rukopisů 16 . a 17. století a některé další problémy teoretické a terminologické. In: XI. seminár restaurátorů a historiků: referáty, Litoméřce, 13.-16. 9. 2000. Praha: Státní ústřední archiv, 2003, s. 52-65.

OTTŮV SLOVNÍK 1898: Ottův slovník naučný: illustrovaná encyklopedie obecných vědomostí. 13. díl, Jana-Kartas. V Praze: J. Otto, 1898, s. 548.

OTTU゚V SLOVNÍK 1899: Ottưv slovník naučný: illustrovaná encyklopaedie obecných vědomostí. 14. díl, KartelKraj. V Praze: J. Otto, 1899, s. 439-441, s. 1057-1058.

OTTŮV SLOVNÍK 1907: Otti̊v slovnik naučný: Ilustrovaná encyklopedie obecných vědomostí. 26. díl, U-Vusín. V Praze: J. Otto, 1907, s. 239.

OTTŮV SLOVNÍK 1908: Ottưv slovník naučný: Ilustrovaná encyklopedie obecných vědomostí. 27. díl, VůzŽyžkowski. V Praze: J. Otto, 1908, s. 421.

PETR 2007: PETR, Stanislav. Soupis rukopisu knihovny při farním kostele svatého Jakuba v Brně. Praha: Masarykův ústav a Archiv AV Č, 2007. Studie o rukopisech. Monographia, sv. 12.

PRAŽÁK 1969: PRAŽÁK, Jiří (ed.). Rukopisy křivoklátské knihovny. Praha: Národní muzeum, 1969. Knihovna Národního muzea. Katalogy a inventáře; č. 9.

PRAŽÁK 1980: PRAŽÁK, Jiří. Katalog rukopisů křižovnické knihovny, nyní deponovaných ve Státní knihovně ČSR v Praze. Praha: Státní knihovna ČSR, 1980. Edice Sektoru služeb a speciálních oddělení.

PRAŽÁK - HOFFMANN 1983: PRAŽÁK, Jiří HOFFMANN, František - KEJŘ, Jiří - ZACHOVÁ, Irena. Zásady popisu rukopisů. Sborník Národního muzea, rada C-Literární historie 28, 1983, č. 2, s. 49-95.

RHEIN 1942: RHEIN, Adolf. Kapitalbünde. $\mathrm{Zu}$ einem Katalog Die Frühdruckeinbände der Stadtbücherei Erfurt. Archiv für Buchbinderei 42, 1942, s. 89-92.

ROČENKA 1958: Ročenka Universitni knihovny v Praze 1956. Praha: Státní pedagogické nakladatelství, 1958. Edice Universitní knihovny v Praze. Edice publikace vědecké literatury.

ROŠICKÝ 1894a: ROŠICKÝ, Václav L. Knihařství. V Praze: I. L. Kober, 1894.

ROŠICKÝ 1894b: ROŠICKÝ, Václav L. Koželužství. In: Chemie denniho života, část 2. V Praze: I. L. Kober, 1894. Kronika práce, osvěty, průmyslu a nálezův, díl 6.

RYBA 1979: RYBA, Bohumil. Soupis rukopisů Strahovské knihovny Památníku národního písemnictví v Praze. Praha: Památník národního písemnictví, 1970-1979. 6 sv.
RYBA 1980: RYBA, Bohumil. Soupisy rukopisü a starých tiski̊ do r. 1800 z fondi Krajské knihovny v Českých Budějovicích: rukopisy kláštera ve Vyšším Brodě. 2 sv. České Budějovice: Státní vědecká knihovna, 1980.

ŘEHÁK - ORLITA 1986. ŘEHÁK, Petr - ORLITA, Alois. Přehled konzervačnich metod použivaných v oddělení ochrany a restaurování fondů Státni knihovny ČSR. Díl III., Technologický předpis pro konzervaci bilých vazebnich usní a pergamenů zejména z obdobi 16. a 17. století. Praha: Státní knihovna ČSR, 1986.

SLOVIK - SOJKOVÁ - KOPÁČIK 2015: SLOVIK, Radomír; SOJKOVÁ, Karina a KOPÁČIK, Ivan. Ateliér restaurování papíru, knižní vazby a dokumentũ: didaktické návody. Litomyšl: Univerzita Pardubice, Fakulta restaurování, 2015.

SLOVIK-VÁVROVÁ - SLOVIK 2018: SLOVIK-VÁVROVÁ, Hana - SLOVIK, Radomír. Celokovové vazby 19. století. Acta Musei nationalis Pragae - Historia litterarum 63, 2018, č. 3-4, s. 96-104.

STOCKÝ 1927: STOCKÝ, Albín. Konservace musejnich predmětů. V Praze: Nákladem Svazu československých museí, 1927. Knihovna Svazu československých museí; sv. 1.

SVOBODOVÁ 1996: SVOBODOVÁ, Milada. Katalog českých a slovenských rukopisů sign. XVII ziskaných Národni (Universitní) knihovnou po vydáni Truhlárova katalogu z roku 1906. Praha, 1996. (České rukopisy signatury XVII.)

SZIRMAI 1999: SZIRMAI, János Alexander. The Archaeology of Medieval Bookbinding. Aldershot: Ashgate, 1999.

ŠEDIVÝ 1923: ŠEDIVÝ, Jan. Vázání knih: návod pro učitele ručnich prací. V Praze: Nákladem Ústředního nakladatelství a knihkupectví učitelstva českoslovanského, 1923. Příručky činné školy, sv. 3.

ŠETLÍK 1910: ŠETLÍK, Břetislav. Chemická technologie pro knihaře a príbuzná odvětví. V Praze: Tiskem a nákladem Emanuela Stivína, 1910. Sbírka odborných spisů, rozprav a pojednání pro průmyslové školy a praxi; čís. 1.

TOBOLKA 1950: TOBOLKA, Zdeněk Václav. Kniha: jeji vznik, vývoj a rozbor. Praha: Orbis, 1950.

VAKRČKA 1979: VAKRČKA, Alois. Knihařství: technologie ručni vazby: učebni text pro OU a UŠ. Praha: SPN, 1979. VAŠICA - VAJS 1957: VAŠICA, Josef - VAJS, Josef. Soupis staroslovanských rukopisů Národního musea v Praze. Praha: Nakladatelství Československé akademie věd, 1957. VÁVROVÁ - SOUČKOVÁ 2017: VÁVROVÁ, Petra SOUČKOVÁ, Magda (edd.). Konzervace a restaurování novodobých knihovních fondu․ Praha: Národní knihovna ČR, 2017.

VOIT 2006: VOIT, Petr. Encyklopedie knihy: starši knihtisk a príbuzné obory mezi polovinou 15. a počátkem 19. století. Praha: Libri ve spolupráci s Královskou kanonií premonstrátů na Strahově, 2006. Bibliotheca Strahoviensis. Series monographica; 2.

VOIT 2015: VOIT, Petr. Katalog prvotiski̊ Strahovské knihovny v Praze. Praha: Královská kanonie premonstrátů na Strahově, 2015. Bibliotheca Strahoviensis. Series monographica, 6.

VOJTÍŠEK 1914: VOJTÍŠEK, Václav. Konservace archiválií. Praha: [vl. n.], 1914. 
VOJTÍŠEK 1932: VOJTÍŠEK, Václav. O konservaci archiválií. Praha: [vl. n.], 1932.

VNOUČEK 1992: VNOUČEK, Jiř́. Knihy v ohrožení: lze restaurovat středověké knihy, aniž by došlo ke ztrátám informací? In: VIII. seminár restaurátorů a historiků: referáty: Železná Ruda - Špičák, 25.-27. června 1991. Praha: Státní ústřední archiv, 1992, s. 127-152. Zpravodaj pobočky ČIS, č. 39 .

WATERS 1998: WATERS, Peter. Phased Conservation. Book and Paper Group Annual 17, 1998, s. 113-122. Dostupné z: http://cool.conservation-us.org/coolaic/sg/bpg/ annual/

WINTER 1906: WINTER, Zikmund. Dějiny řemesel a obchodu v Čechách v XIV. a v XV. století. V Praze: Nákladem České akademie císaře Františka Josefa pro vědy, slovesnost a umění, 1906. Spisy musejní, č. 170.

ZACHOVÁ - PETR 2010: ZACHOVÁ, Irena - PETR, Stanislav. Soupis sbirky rukopisů bývalého Františkova muzea - fondu G 11 Moravského zemského archivu v Brné. Praha: Masarykův ústav a Archiv AV ČR, 2010. Studie o rukopisech. Monographia, sv. 14.

ZUMAN - VYKYDAL - KORDA 1983: ZUMAN, František - VYKYDAL, Miroslav - KORDA, Josef (edd.). Papir: historie řemesla a výrobní techniky. [s. 1.]: 1983. Vyšlo jako př́loha časopisu Papír a celulóza.

\section{Terminologické slovníky a elektronické zdroje:}

Encyklopedie knihy [online]. Knihovna AV ČR. [Cit. 24. 1. 2020]. Dostupné z: https://www.encyklopedieknihy.cz/index. php/Hlavn\%C3\%AD_strana

Glossary on Paper Conservation in Six Languages [online]. Goethe-Institut. [Cit. 27. 1. 2020]. Dostupné z: https://www. goethe.de/ins/cn/en/sta/hon/bib/glossarpapier.html
GNIRREP, W. K. - GUMBERT, J. P. - SZIRMAI, J. A. Kneep en Binding: een terminologie voor de beschrijving van de constructies van oude boekbanden. Den Haag: Koninklijke Bibliotheek, 1992. Dostupné také z: https:// www.kb.nl/sites/default/files/docs/kneep_en_binding_digitaal_20080410.pdf

LANGEROVÁ, Johana. Výkladový slovník odborných terminů použivaných při konzervováni a restaurování archiválii. Praha: Národní archiv, 2015.

Language of Binding [online]. University of the Arts. [Cit. 26. 1. 2020]. Dostupné z: http://www.ligatus.org.uk/lob/ Medieval Manuscripts: Bookbinding Terms, Materials, Methods, and Models [online]. Yale University Library. [Cit. 27. 1. 2020]. Dostupné z: https://travelingscriptorium.files. wordpress.com/2013/07/bookbinding-booklet.pdf

reCollections: Caring for Collections Across Australia. Canberra: Heritage Collections Council, 1998. Dostupné také z: https://aiccm.org.au/conservation/collection-care

ROBERTS - ETHERINGTON 1982: ROBERTS, Matt ETHERINGTON, Don. Bookbinding and the Conservation of Books: A Dictionary of Descriptive Terminology. Washington: Library of Congress, 1982. Dostupné také z: https://cool.culturalheritage.org/don/toc/toc1.html

\author{
| Jan Novotný \\ Knihovna Národního muzea \\ oddělení rukopisů a starých tisků \\ Vinohradská 1 \\ 11000 Praha 1
}

